\title{
A széntartalmú légköri aeroszol forrásai és jelentősége
}

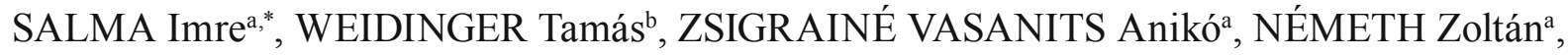 \\ FARKAS Gergö ${ }^{a}$, VARGA Veronika ${ }^{a}$
}

${ }^{a}$ ELTE Kémiai Intézet, Pázmány Péter stny. 1/A, 1117 Budapest, Magyarország

${ }^{b}$ ELTE Meteorológiai Tanszék, Pázmány Péter stny. 1/A, 1117 Budapest, Magyarország

\section{Bevezetés}

A Budapest Aeroszol Kutató és Oktató Platform (Budapest platform for Aerosol Research and Training, BpART, http:// salma.web.elte.hu/BpArt, 1. Ábra) 2013. október óta müködik. ${ }^{1}$ Fö céljai között szerepel a levegőkörnyezetre vonatkozó tudományos ismeretek megszerzése és bővítése. A kutatási irányok az aeroszol keletkezését, kémiai és fizikai tulajdonságait, illetve folyamatait, valamint az egészségi, az éghajlati és a környezeti hatásait egyaránt magukba foglalják. A BpART csapata és infrastruktúrája az ELTE Kémiai Intézet önálló kutatólaboratóriumává vált, és bekapcsolódott a klímaadaptív és fenntartható hazai mezőgazdaságot szolgáló, multidiszciplináris kutatóműhely (AGROMO) munkájába is. A kutatóállomás többször helyszínül szolgált nemzetközi és hazai tudományos együttmüködéseknek. Az elért eredmények sajátos alkalmazása a levegőminőségre vonatkozó háttér-információk és értékelések készítése fővárosi szakreferensek vagy döntést előkészítők számára. ${ }^{2} \mathrm{Az}$ egyik legfőbb kutatási témánkat, a budapesti légköri nukleáció jelenségét és következményeit az elmúlt évben tárgyaltuk e folyóirat lapjain. ${ }^{3}$ A jelenlegi, munkabeszámoló jellegü összefoglalójában ezért egy másik fontos témakörben, a széntartalmú aeroszol komponensek keletkezésének és tulajdonságainak a területén elért, újabb tudományos eredményeinket és következtetéseinket ismertetjük tömören.

\section{Széntartalmú aeroszol komponensek}

A széntartalmú aeroszol összetevők főleg kormot és szerves vegyületeket foglalnak magukba. A kormot elemi szénnel (elemental carbon, EC) lehet közelíteni. A szerves összetevők csoportját ezret meghaladó számú, egyedi vegyület alkotja, amelyet a szerves vegyületekben lévő szénnel (organic carbon, OC) lehet összefoglalóan jellemezni. A széntartalmú összetevők a finom méretű aeroszol részecskék tömegének akár $50 \%$-át is alkothatják. ${ }^{4}$ Ennek köszönhetően, illetve egyedi vegyületeik különleges tulajdonságai és hatásai miatt fontos szerepet játszanak életünkben az egészségügyi, éghajlati és környezeti jelentőségüket tekintve, ezért szükséges a fö forrástípusaik és relatív jelentőségük megismerése a Kárpát-medencében és azon belül Budapesten. ${ }^{5} \mathrm{~A}$ fö források a biogén (leginkább növényi) emissziót követő légkörkémiai képződési folyamatok, valamint a széntartalmú anyagok, nevezetesen a fosszilis üzemanyagok (fossil fuel, FF) tüzelése, illetve a biomassza égetése (biomass burning, BB). Ezek a források finom méretfrakciójú részecskéket eredményeznek, amelyeket a 2,5 $\mu$ m-nél kisebb aerodinamikai átmérővel rendelkező részecskék halmazával $\left(\mathrm{PM}_{2,5}\right.$ mérettartomány) jellemezhetünk.

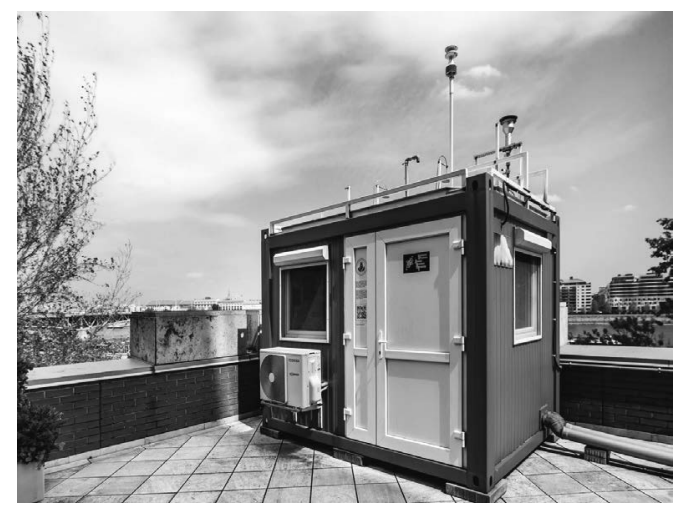

1. Ábra. A Budapest Aeroszol Kutató és Oktató Platform (BpART) kutatólaboratórium látképe 2019. áprilisban (Fotó: Csomós Attila).

A biomassza égetése erdőtüzeket, mezőgazdasági tüzeket, illetve fa, szalma és szerves hulladék háztartási és ipari méretü égetését foglalja magába fütési, főzési vagy kedvtelési céllal. ${ }^{6} \mathrm{~A}$ háztartási és ipari égetési formáknak fontos szerepe lehet a decentralizált energiatermelésben, illetve a fosszilis tüzelőanyagok helyettesítésében. A legnagyobb mennyiségben égetett biomassza a fa, amelynek fó kémiai építőelemei a cellulóz, a hemicellulóz és a ligninek. A cellulóz lineáris biopolimer, amely D-glükóz monomer egységekből épül fel. ${ }^{7}$ A hemicellulóz kevésbé szabályos szerkezetü, fő monomerjei a glükóz, a mannóz, a galaktóz és a xilóz. A fa lángoló égése közben $\left(300{ }^{\circ} \mathrm{C}\right.$ feletti hőmérsékleten) anhidrocukrok, illetve illékony szerves vegyületek keletkeznek, amelyek a lángban tovább oxidálódnak. Az égéstermékek közül jelentős mennyiségben előforduló komponensek a levoglükozán (LVG, 1,6-anhidro- $\beta$-D-glükopiranóz) és térizomerjei, a mannozán (1,6-anhidro- $\beta$-D-mannopiranóz), illetve a galaktozán (1,6-anhidro- $\beta$-D-galaktopiranóz). Ezek a vegyületek az aeroszol részecskékre kondenzálódnak, amikor a füstgáz hőmérséklete csökken. A vegyületek stabilnak tekinthetők a levegőben az aeroszol 7-10 napos légköri tartózkodási ideje alatt, ezért a BB molekuláris markereként alkalmazhatók. ${ }^{8}$ A fosszilis anyagok égetésével keletkezett széntartalmú összetevőket a ${ }^{14} \mathrm{C}$ (radiokarbon) mérésével lehet megkülönböztetni a többi forrástól. ${ }^{9}$

Fő szerző. Tel.: +1 372-26-15; E-mail: salma@chem.elte.hu. 


\section{Módszerek}

Aeroszol mintákat gyüjtöttünk többféle módszerrel, majd ezeket különböző analitikai módszerekkel mértük. A kísérleti eredményeket modellszámítások keretében értékeltük és értelmeztük.

\subsection{Aeroszol mintavétel és in situ mérések}

Egy évet átfogó, összehasonlító vizsgálatokhoz azonos típusú (Digitel DHA-80 nagy térfogatáramú) mintavevővel gyüjtöttünk napi aeroszol mintákat kvarcszálas szürőkre, párhuzamosan 3 helyszínen 2017. október, 2018. január, április és július hónapokban, évszakonként 2 hétig. A mintagyüjtések a BpART Laboratóriumban, az Országos Meteorológiai Szolgálat (OMSz) Marczell György Főobszervatóriumában és a K-pusztai mérőállomáson történtek, amelyek a budapesti belváros, a külváros és a regionális (vidéki) háttér levegőkörnyezeteket képviselik. A BpART Laboratóriumban 11 fokozatú, MOUDI kaszkád impaktorral is gyüjtöttünk aeroszol mintákat polikarbonát fóliákra a 0,053-9,9 $\mu \mathrm{m}$ aerodinamikai átmérőtartományban. A mintagyüjtéseket a kulcsfontosságú légszennyezők $\left(\mathrm{SO}_{2}, \mathrm{CO}, \mathrm{NO}, \mathrm{NO}_{\mathrm{x}}, \mathrm{O}_{3}, \mathrm{PM}_{10}\right.$ tömeg) és meteorológiai adatok (levegőhőmérséklet, relatív páratartalom, szélsebesség és -irány, globális napsugárzás) standardizált, on-line mérésével egészítettük ki.

\subsection{Laboratóriumi mérések}

Az aeroszol minták tömegét gravimetriával mértük, elemi összetételét atomabszopciós spektrometriával határoztuk meg, EC és OC tartalmát termikus-optikai transzmisszió (TOT) módszerrel állapítottuk meg EUSAAR2 hőmérsékleti protokollt használva, míg az anhidrocukrok meghatározását származékképzést követően gázkromatográfia tömegspektrométerrel (GC-MS) ${ }^{10,11}$ mértük. Ez utóbbi analitikai módszerhez a mintákat diklór-metán és metanol elegyében oldottuk, az extraktumokat metil- $\beta$-L-arabinopiranóz, standard oldattal adalékoltuk, majd piridin és hexametil-diszilazán (szililezőszer) és trifluór-ecetsav (katalizátor) elegyével kezeltük. A GC-MS méréseket on-column injektálási módban végeztük. A teljes szén modern szénre korrigált $f_{\mathrm{c}}=\left({ }^{14} \mathrm{C} /{ }^{12} \mathrm{C}\right)_{\text {minta }} /\left({ }^{14} \mathrm{C} /{ }^{12} \mathrm{C}\right)_{\mathrm{OA}}$ arányát (ahol $\mathrm{OA}$ alsó index az oxálsav II standard referencia anyagot jelöli) Mini Carbon Dating System gyorsító-tömegspektrometria (accelarator mass spectrometry, AMS) módszerrel határozták meg részünkre az MTA ATOMKI szakemberei. ${ }^{12}$

\subsection{Adatkiértékelés és modellezés}

A biomassza égetés járulékát a $\mathrm{PM}_{2,5}$ aeroszol tömeghez LVG marker modellel számoltuk. ${ }^{13}$ Az EC és OC specieszek forrásmegosztását a fosszilis tüzelés, a biomassza égetés és biogén emisszió tekintetében az összekapcsolt LVGradiokarbon marker modellel végeztük el. ${ }^{5} \mathrm{~A}$ forrásmegosztás folyamatát a 2. Ábrán szemléltetjük: $f_{1}=f_{\mathrm{c}} ; f_{2}=(\mathrm{OC} / \mathrm{LVG})$ ${ }_{\mathrm{BB}} \times \mathrm{LVG} \times(\mathrm{EC} / \mathrm{OC})_{\mathrm{BB}} / f_{1} / \mathrm{TC} ; f_{3}=(\mathrm{OC} / \mathrm{LVG})_{\mathrm{BB}} \times \mathrm{LVG} / f_{1} /\left(1-f_{2}\right) /$
TC és $f_{4}=\left(\mathrm{EC} / \mathrm{TC}-f_{1} \times f_{2}\right) /\left(1-f_{1}\right)$, ahol $\mathrm{TC}=\mathrm{EC}+\mathrm{OC}$, illetve $(\mathrm{EC} / \mathrm{OC})_{\mathrm{BB}}=17 \%$ és $(\mathrm{OC} / \mathrm{LVG})_{\mathrm{BB}}=5,59$ irodalmi forrásokból származó értékek. ${ }^{5,9,14}$

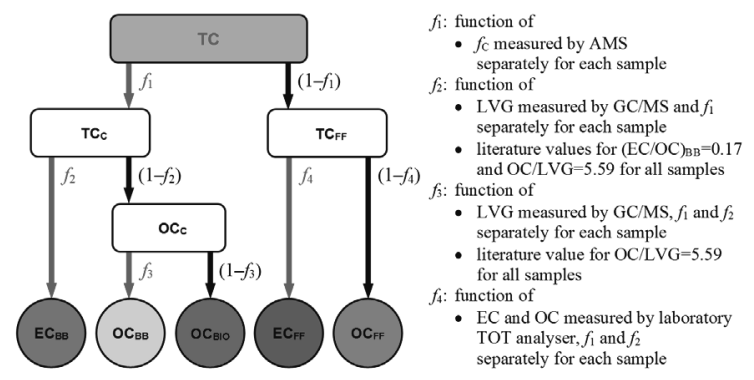

2. Ábra. Az elemi szén (EC) és a szerves szén (OC) forrásmegosztása a fosszilis anyagok (FF) tüzelése, a biomassza égetés (BB) és biogén források (BIO) között a levoglükozán-radiokarbon összekapcsolt marker modellel. A $c$ alsó index a modern eredetü (contemporary/modern;

BB és BIO eredetü) szén-specieszeket jelöli, illetve $\mathrm{TC}=\mathrm{EC}+\mathrm{OC}$.

Az anhidrocukrok méreteloszlásainak meghatározását MICRON adatinverziós számítógépes eljárással valósítottuk meg. ${ }^{11,15-16}$ A módus paramétereket lognormális eloszlás-függvények illesztésével számítottuk ki.

\section{Eredmények és követeztetések}

\subsection{Légköri koncentrációk}

A fontosabb aeroszol összetevők légköri koncentrációi jelentős és tendenciózus változást mutattak a különböző levegőkörnyezeteket, illetve évszakokat tekintve (1. Táblázat).

\begin{tabular}{llllll}
\hline Összetevő & Helyszín & Ösz & Tél & Tavasz & Nyár \\
\hline $\mathrm{PM}_{2,5}$ & vidék & 12,5 & 15,4 & 7,9 & 10,7 \\
$\left(\mu \mathrm{g} \mathrm{m}^{-3}\right)$ & külváros & 25 & 27 & 9,7 & 11,7 \\
& belváros & 28 & 24 & 13,3 & 8,1 \\
$\mathrm{EC}$ & vidék & 0,41 & 0,36 & 0,20 & 0,12 \\
$\left(\mu \mathrm{g} \mathrm{m}^{-3}\right)$ & külváros & 0,42 & 0,68 & 0,51 & 0,35 \\
& belváros & 1,00 & 0,77 & 0,79 & 0,37 \\
$\mathrm{OC}$ & vidék & 2,3 & 3,2 & 2,0 & 2,2 \\
$\left(\mu \mathrm{g} \mathrm{m}^{-3}\right)$ & külváros & 4,0 & 5,4 & 2,4 & 2,7 \\
& belváros & 6,6 & 4,6 & 2,8 & 2,6 \\
$\left.\mathrm{LVG}^{-3}\right)$ & vidék & 0,172 & 0,40 & 0,0180 & 0,0081 \\
$\left(\mu \mathrm{g} \mathrm{m}^{-3}\right)$ & külváros & 0,44 & 0,71 & 0,040 & 0,0124 \\
& belváros & 0,38 & 0,48 & 0,036 & 0,0103 \\
$\mathrm{~K}$ & vidék & 0,182 & 0,23 & 0,088 & 0,081 \\
$\left(\mu \mathrm{g} \mathrm{m}^{-3}\right)$ & külváros & 0,22 & 0,25 & 0,097 & 0,075 \\
& belváros & 0,26 & 0,27 & 0,106 & 0,057 \\
$f_{\mathrm{c}}$ & vidék & 69 & 75 & 61 & 74 \\
$(\%)$ & külváros & 66 & 74 & 48 & 60 \\
& belváros & 76 & 74 & 48 & 60 \\
\hline & & & &
\end{tabular}

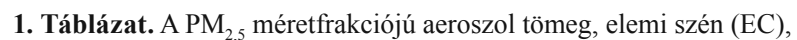
szerves szén (OC), levoglükozán (LVG) és K medián koncentrációi és a teljes széntartalom modern-szén tartalma $\left(f_{\mathrm{C}}\right)$ Budapest regionális hátterében (vidék), külvárosában és belvárosában, a 4 évszakban. 

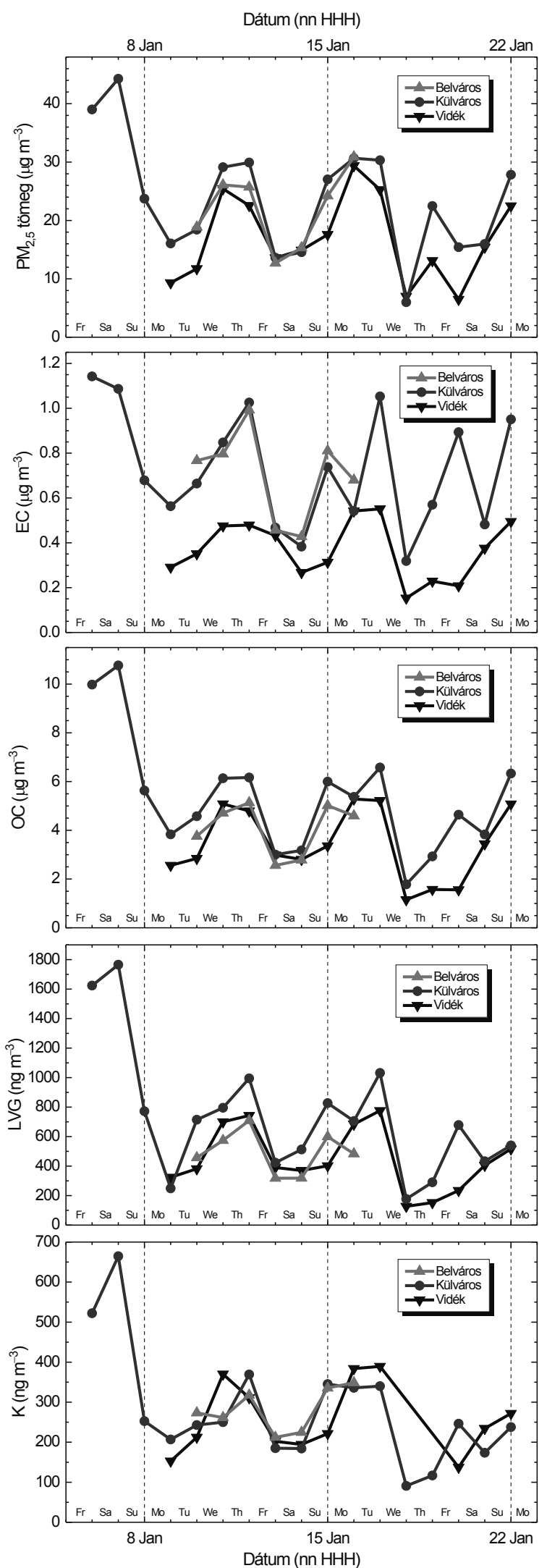

3. Ábra. $\mathrm{APM}_{2,5}$ méretfrakciójú aeroszol tömeg, elemi szén (EC), szerves szén (OC), levoglükozán (LVG) és K napi átlagos koncentrációjának változékonysága Budapest belvárosában, külvárosában és regionális háttérkörnyezetében (vidék) télen. A hét napjait szintén jelöltük az ábrákon.
Több, különböző forrásból származó aeroszol összetevő (és légszennyező gáz) napi átlagos légköri koncentrációja együtt változott a mérési kampány alatt ősszel és különösen télen (3. Ábra). Mindez a helyi és regionális meteorológiai viszonyok és a nagy hatótávolságú transzport folyamatok fontosabb, meghatározóbb szerepét jelzi a helyi vagy regionális forrásokkal összehasonlítva. ${ }^{17}$ Nyáron nem volt kimutatható hasonló kapcsolat. Mindez egybevág a Kárpátmedencében télen, anticiklonális időjárási helyzetekben tapasztalható, nagyobb kiterjedésü, időnként komolyabb levegőszennyezettség kialakulásával, valamint ennek térbeli és időbeli eloszlásával kapcsolatos elképzelésekkel, amelyek elsősorban az ún. hidegpárna meteorológiai helyzetekkel magyarázhatók.

\subsection{Járulékok}

A fontosabb járulékokat a 2 . Táblázatban összegeztük. ${ }^{18} \mathrm{~A}$ korom az aeroszol tömeg 1-5\%-át teszi ki, és járuléka, valamint koncentrációja is növekvő tendenciát mutat a vidéki háttértől a külvároson keresztül a belváros felé. Ez elsősorban a közlekedési eredetü EC-vel magyarázható. Az őszi járulék a regionális háttérben a mezőgazdasági tüzekkel lehet kapcsolatban. A szerves anyag (organic matter, OM) mennyiségét a belvárosban, illetve a külvárosban és a vidéki háttérhelyen $\mathrm{OM} / \mathrm{OC}=1,6$, illetve 1,4 konverziós tényezővel becsültük, tekintettel a belvárosi levegő várhatóan nagyobb oxidációs hatására a másik 2 helyszínnel összehasonlítva. ${ }^{14} \mathrm{Az}$ OM járulékának nincs markáns évszakos, továbbá a levegőkörnyezet típusával kapcsolatos tendenciózus változása. Járuléka lényegében állandó: $(33 \pm 4) \%$, ami a legnagyobb egyedi járulékot képviseli. Mindez azzal függ össze, hogy az OC sokféle típusú és elhelyezkedésü emiszsziós és képződési folyamatban keletkezik, amelyek kiegészítik vagy kiegyenlítik egymást. A BB járuléka a szerves szénhez télen tipikusan eléri a kb. $70 \%$-ot, és jelentősen csökkent az ősz, tavasz és nyár sorrendben. A regionális érték ősszel itt is kissé nagyobbnak tünik a másik kettővel összehasonlítva. A nyári értékek csupán 2-3\% körüliek. A BB járulékának a külvárosban alakult ki maximuma a helyszínek tekintetében, ami a fatüzelés sajátosságaival, föleg időbeli és térbeli előfordulásával magyarázható.

\begin{tabular}{llllll}
\hline Arány & Helyszín & Ösz & Tél & Tavasz & Nyár \\
\hline $\mathrm{EC} \mathrm{PM}_{2,5}$ & vidék & $4,0 \pm 1,8$ & $2,3 \pm 0,5$ & $2,3 \pm 0,7$ & $1,24 \pm 0,32$ \\
$(\%)$ & külváros & $2,7 \pm 1,5$ & $3,1 \pm 0,9$ & $4,9 \pm 2,2$ & $3,5 \pm 1,1$ \\
& belváros & $4,3 \pm 2,4$ & $3,3 \pm 0,6$ & $6,4 \pm 1,7$ & $4,6 \pm 0,9$ \\
$\mathrm{OM} / \mathrm{PM}_{2,5}$ & vidék & $33 \pm 6$ & $29 \pm 5$ & $32 \pm 5$ & $30 \pm 4$ \\
$(\%)$ & külváros & $32 \pm 9$ & $31 \pm 5$ & $32 \pm 6$ & $33 \pm 5$ \\
& belváros & $36 \pm 5$ & $30 \pm 3$ & $30 \pm 4$ & $43 \pm 5$ \\
$\mathrm{OC}_{\mathrm{BB}} / \mathrm{OC}$ & vidék & $37 \pm 6$ & $72 \pm 10$ & $5,3 \pm 3,0$ & $2,0 \pm 0,5$ \\
$(\%)$ & külváros & $35 \pm 9$ & $74 \pm 17$ & $11,0 \pm 5,0$ & $3,1 \pm 1,8$ \\
& belváros & $37 \pm 13$ & $67 \pm 6$ & $9,6 \pm 4,0$ & $2,4 \pm 0,5$ \\
\hline
\end{tabular}

2. Táblázat. Az elemi szén (EC) és szerves anyag $(\mathrm{OM})$ átlagos járuléka és szórása a $\mathrm{PM}_{2,5}$ aeroszol tömeghez, valamint a biomassza égetésből származó szerves szén $\left(\mathrm{OC}_{\mathrm{BB}}\right)$ átlagos járuléka és szórása a szerves szénhez (OC) Budapest regionális hátterében (vidék), külvárosában és belvárosában a 4 évszakban. 


\subsection{Forrásmegoszlás}

A széntartalmú kémiai specieszek felosztásának főbb eredményeit a 3 forrástípus között a 3. Táblázatban foglaltuk össze. ${ }^{18} \mathrm{~A}$ fosszilis üzemanyagok tüzelése viszonylag állandó arányban járul hozzá a TC-hez, míg a BB és a biogén források járuléka nagymértékben változik évszakonként. Összel a 3 fö forrástípus közel azonos jelentőségü, télen a BB a meghatározó forrás mindegyik környezetben, tavaszszal az FF és a biogén források dominálnak, míg nyáron a biogén forrástípus válik meghatározóvá. Nyáron a BB alig kvantifikálható, míg a biogén forrás jelentősége télen sem elhanyagolható. A részecskék higroszkópos, illetve illékony tulajdonságaiból az aeroszol rendszer keveredési állapotára és az egyedi részecskék szerkezetére következtettünk. ${ }^{19}$

\begin{tabular}{|c|c|c|c|c|c|}
\hline Helyszín & Speciesz & Ösz & Tél & Tavasz & Nyár \\
\hline \multirow[t]{6}{*}{ vidék } & $\mathrm{TC}\left(\mu \mathrm{g} \mathrm{m}^{-3}\right)$ & 4,7 & 3,7 & 2,4 & 2,4 \\
\hline & $\mathrm{EC}_{\mathrm{FF}}(\%)$ & 9 & 2 & 10 & 5 \\
\hline & $\mathrm{OC}_{\mathrm{FF}}(\%)$ & 22 & 26 & 32 & 24 \\
\hline & $\mathrm{EC}_{\mathrm{BB}}(\%)$ & 5 & 9 & 1 & $<1$ \\
\hline & $\mathrm{OC}_{\mathrm{BB}}(\%)$ & 31 & 61 & 6 & 2 \\
\hline & $\mathrm{OC}_{\mathrm{BIO}}(\%)$ & 33 & 5 & 56 & 72 \\
\hline \multirow[t]{6}{*}{ külváros } & $\mathrm{TC}\left(\mu \mathrm{g} \mathrm{m}^{-3}\right)$ & 8,1 & 5,9 & 3,2 & 3,0 \\
\hline & $\mathrm{EC}_{\mathrm{FF}}(\%)$ & 4 & 2 & 18 & 13 \\
\hline & $\mathrm{OC}_{\mathrm{FF}}(\%)$ & 28 & 22 & 32 & 26 \\
\hline & $\mathrm{EC}_{\mathrm{BB}}(\%)$ & 6 & 11 & 2 & $<1$ \\
\hline & $\mathrm{OC}_{\mathrm{BB}}(\%)$ & 33 & 61 & 10 & 2 \\
\hline & $\mathrm{OC}_{\mathrm{BIO}}(\%)$ & 30 & 8 & 38 & 59 \\
\hline \multirow[t]{6}{*}{ belváros } & $\mathrm{TC}\left(\mu \mathrm{g} \mathrm{m}^{-3}\right)$ & 8,4 & 5,3 & 3,6 & 2,9 \\
\hline & $\mathrm{EC}_{\mathrm{FF}}(\%)$ & 7 & 5 & 22 & 13 \\
\hline & $\mathrm{OC}_{\mathrm{FF}}(\%)$ & 20 & 21 & 28 & 29 \\
\hline & $\mathrm{EC}_{\mathrm{BB}}(\%)$ & 4 & 10 & 1 & $<1$ \\
\hline & $\mathrm{OC}_{\mathrm{BB}}(\%)$ & 26 & 57 & 8 & 2 \\
\hline & $\mathrm{OC}_{\mathrm{BIO}}(\%)$ & 43 & 8 & 41 & 56 \\
\hline
\end{tabular}

3. Táblázat. A fosszilis (FF) tüzelésből származó elemi szén (EC) és szerves szén (OC), a biomassza égetésből (BB) keletkező EC és OC, illetve a biogén emisszióból (BIO) létrejött OC medián járuléka a teljes szénhez ( $\mathrm{TC}=\mathrm{EC}+\mathrm{OC})$ Budapest regionális hátterében (vidék), külvárosában és belvárosában a 4 évszakban.

\subsection{Méreteloszlások}

Az anhidrocukrok tömeg méreteloszlásában 3 módus jelent meg (4. Ábra). ${ }^{11}$ A legnagyobb csúcsot (Módus 1) a biomassza égetéshez rendelhetjük (kondenzációs almódus). A Módus 2 (csepp almódus) az előbbi csúcsból alakult ki a részecskék és a vízgőz közötti kölcsönhatással (víz-processzálással), míg a Módus 3 a lignit égetéssel lehet kapcsolatos. A módusok medián átmérője rendre $0,42,1,62$ és $0,11 \mu \mathrm{m}$, geometriai szórása $1,70,1,71$ és 1,39 , relatív módusterülete pedig 90\%, 9\% és 9\%. Mindez azt jelzi, hogy a lignitből származó LVG mennyiség általában elhanyagolható arányú, és ezért a LVG-t a biomassza (fa) égetés alkalmas molekuláris markerének tekinthetjük a Kárpát-medencében.

\section{5. Összefoglalás és kitekintés}

Jelen tanulmányban tömör áttekintést adtunk az ELTE BpART Laboratórium keretében az elmúlt 3 évben végzett munka egyik fontos területéröl, a széntartalmú aeroszol összetevők kémiai és fizikai folyamatairól, jelentőségéről, illetve környezeti és éghajlati hatásairól. Az elért tudományos eredmények és következtetések teljesebb, illetve részletesebb bemutatása, megvitatása és értelmezése megtalálható a feltüntetett közleményeinkben, ${ }^{20}$ valamint a BpART Laboratórium honlapján.
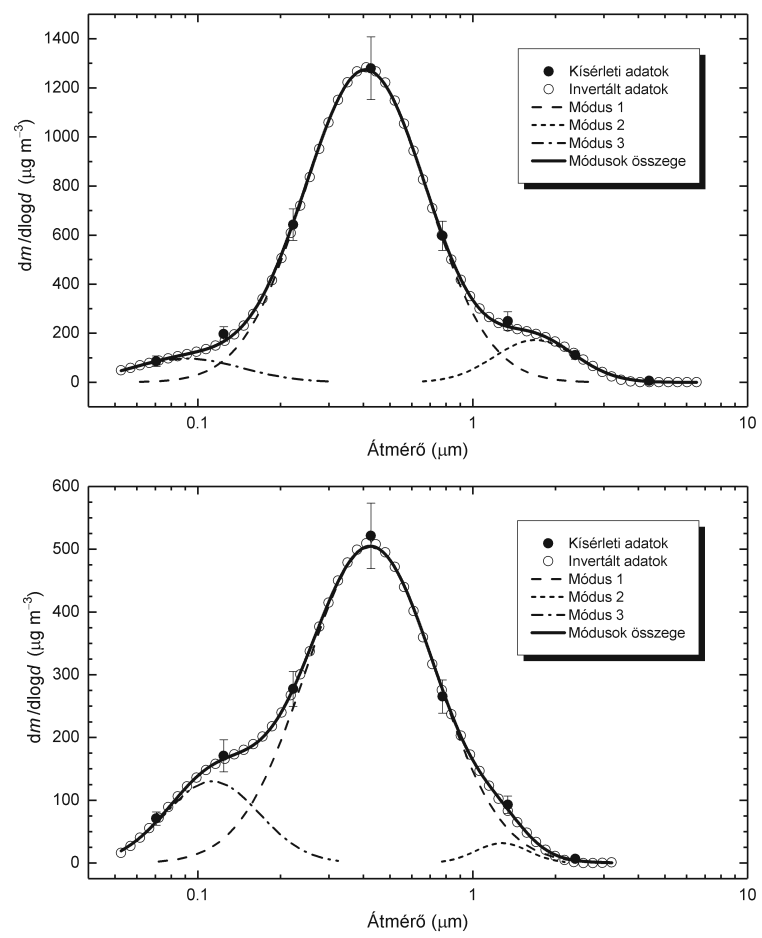

4. Ábra. A levoglükozán tömeg méreteloszlása Budapest belvárosában két, különböző napon a téli időszakban.

Végezetül megjegyezzük, hogy a levegőminőség javítását célzó országos programokban érdemes nagyobb hangsúlyt fektetni a biomassza égetésre, mert kedvező fejleményeket lehet elérni a háztartási fütés és tüzelés korszerüsítésével, különösen pedig a lakosság felvilágosításával és oktatásával, illetve a környezettudatos szemléletének erösítésével.

\section{Köszönetnyilvánítás}

A kutatómunkát az NKFIH (K116788, K132254), valamint a Széchenyi 2020 program, Magyarország Kormánya és az Európai Regionális Fejlesztési Alap (GINOP-2.3.2-15-2016-00028 és GINOP-2.3.2-15-2016-00055) támogatta. Köszönetünket fejezzük ki Varga J. Debóra hallgatónak a GC-MS analízis mintáinak előkészítéséért, Blumberger Zoltán hallgatónak a kaszkád impaktor minták gyűjtéséért és feldolgozásáért, Machon Attilának (OMSz) a nagytérfogatú aeroszol minták gyüjtésében nyújtott segítségéért, valamint Molnár Mihálynak és kutatócsoportjának (ATOMKI) az AMS mérésekért. 


\section{Hivatkozások}

1. Salma, I., Németh, Z., Weidinger, T., Kovács, B., Kristóf, G.: Atmos. Chem. Phys. 2016, 16, 7837-7851, https://doi.org/10.5194/acp-16-7837-2016

2. Molnár, Zs. (szerk.): Budapest Környezeti Állapotértékelése 2013-2017, Budapest Főváros Önkormányzata, Budapest.

3. Salma, I., Németh, Z., Varga, V., Weidinger, T.: Magy. Kém. Foly. 2019, 125, 64-68, https://doi.org/10.24100/MKF.2019.02.64

4. Fuzzi, S., Baltensperger, U., Carslaw, K., Decesari, S., Denier van der Gon, H., Facchini, M. C., Fowler, D., Koren, I., Langford, B., Lohmann, U., Nemitz, E., Pandis, S., Riipinen, I., Rudich, Y., Schaap, M., Slowik, J. G., Spracklen, D. V., Vignati, E., Wild, M., Williams, M. Gilardoni, S.: Atmos. Chem. Phys. 2015, 15, 8217-8299, https://doi.org/10.5194/acp-15-8217-2015

5. Salma, I., Németh, Z., Weidinger, T., Maenhaut, W., Claeys, M., Molnár, M., Major, I., Ajtai, T., Utry, N., Bozóki, Z.: Atmos. Chem. Phys. 2017, 17, 13767-13781, https://doi.org/10.5194/acp-17-13767-2017

6. Vicente, E. D., Alves, C. A.: Atmos. Res. 2018, 199, 159-185, https://doi.org/10.1016/j.atmosres.2017.08.027

7. Simoneit, B. R. T., Schauer, J. J., Nolte, C. G., Oros, D. R., Elias, V. O., Fraser, M. P., Rogge, W. F., Cass, G. R.: Atmos. Environ. 1999, 33, 173-182, https://doi.org/10.1016/S1352-2310(98)00145-9

8. Hennigan, C. J., Sullivan, A. P., Collett, Jr. J. L., Robinson, A. L.: Geophys. Res. Lett. 2010, 37, L09806, https://doi.org/10.1029/2010GL043088

9. Szidat, S., Jenk, T. M., Synal, H. A., Kalberer, M., Wacker, L., Hajdas, I., Kasper-Giebl, A., Baltensperger, U.: $J$. Geophys. Res. 2006, 111, D07206. https://doi.org/10.1029/2005JD006590
10. Pashynska, V., Vermeylen, R., Vas, G., Maenhaut, W., Claeys, M.: J. Mass Spectrom. 2002, 37, 1249-125, https://doi.org/10.1002/jms.391

11. Blumberger, Z. I., Vasanits-Zsigrai, A., Farkas, G., Salma, I.: Atmos. Res. 2019, 220, 1-9, https://doi.org/10.1016/j.atmosres.2019.01.001

12. Molnár, M., Rinyu, L., Veres, M., Seiler, M., Wacker, L., Synal, H.-A.: Radiocarbon 2013, 55, 338-344, https://doi.org/10.1017/S0033822200057453

13. Schmidl, C., Marr, L. L., Caseiro, A., Kotianova, P., Berner, A., Bauer, H., Kasper-Giebl, A., Puxbaum, H.: Atmos. Environ. 2008, 42, 126-141, https://doi.org/10.1016/j.atmosenv.2008.09.010

14. Russell, L. M.: Environ. Sci. Technol. 2003, 37, 2982-2987, https://doi.org/10.1021/es026123w

15. Wolfenbarger, J. K., Seinfeld, J. H.: J. Aerosol Sci. 1990, 21, 227-247, https://doi.org/10.1016/0021-8502(90)90007-K

16. Salma, I., Mészáros, T., Maenhaut, W.: J. Aerosol Sci. 2013, $56,53-60$, https://doi.org/10.1016/j.jaerosci.2012.06.006

17. Salma, I., Chi, X., Maenhaut, W.: Atmos. Environ. 2004, 38, $27-36$, https://doi.org/10.1016/j.atmosenv.2003.09.047

18. Salma, I., Vasanits-Zsigrai, A., Machon, A., Varga, T., Major, I., Gergely, V., Molnár, Atmos. Chem. Phys., 2020, 20, 4295-4312, https://doi.org/10.5194/acp-20-4295-2020

19. Enroth, J., Mikkilä, J., Németh, Z., Kulmala, M., Salma, I.: Atmos. Chem. Phys. 2018, 18, 4533-4548, https://doi.org/10.5194/acp-18-4533-2018

20. Salma, I., Borsós, T. Németh, Z.: Magy. Kém. Foly. 2012, 118, 107-114. 


\section{Sources of carbonaceous aerosol components and their importance}

Budapest platform for Aerosol Research and Training (BpART, http://salma.web.elte.hu/BpART) is a laboratory of the Institute of Chemistry, Eötvös University. It serves and advances the research of atmospheric aerosols through complex surface based and satellite born measurements, as well as promotes the education and training of students at master or PhD levels and young/postdoctoral researchers interested in aerosol science. Our scientific interests cover all aspects of tropospheric aerosol research, implications on climate, human health, and built environment, especially studies on urban-type aerosol. One of the major scientific objectives of the laboratory is the atmospheric nucleation phenomenon and its consequences. These issues were, however, presented recently in the present journal, and, therefore, we limit our work progress report now on another important goal of the BpART team, namely on the latest research results and conclusions achieved in the source apportionment of major carbonaceous aerosol constituents and their importance in Budapest and the Carpathian Basin.

Aerosol sample collection campaigns were conducted in city central, suburban and regional background environments of Budapest for 2 weeks in autumn 2017, winter, spring and summer 2018 to quantify the contributions of fossil fuel (FF) combustion, biomass burning (BB) and biogenic (BIO) sources by coupled levoglucosan-radiocarbon marker method, and to interpret their consequences on the air quality in Budapest. Aerosol samples in the $\mathrm{PM}_{25}$ size fraction were collected on quartz fibre filters by identical high-volume samplers. Particulate mass, elemental carbon (EC), organic carbon (OC), levoglucosan (LVG), mannosan (MAN), galactosan (GAN) and $\mathrm{K}$ were determined with a TOT carbon analyser method, GC-MS after silylation, AAS method. Radiocarbon analysis was performed by accelerator mass spectrometry. These constituents are important markers for BB or FF combustion emissions. Contribution of $\mathrm{EC}$ to the $\mathrm{PM}_{2.5}$ mass was $1-5 \%$, and it was increasing from the regional site through the suburban location to the city centre. Organic matter (OM) ac- counted in general $(33 \pm 4) \%$ of the $\mathrm{PM}_{25}$ mass without evident tendentious variation with respect to sites or seasons. Contribution of $\mathrm{OC}$ associated with $\mathrm{BB}\left(\mathrm{OC}_{\mathrm{BB}}=5.54 \times \mathrm{LVG}\right)$ to $\mathrm{OC}$ was ca. $70 \%$ in winter, and it was substantially decreasing for autumn, spring and summer. Its summer value was only $2-3 \%$. The contribution showed a suburban maximum, which was related to the spatial and temporal distributions of BB (mostly wood burning) in the larger area. In general, FF combustion represented $36 \%$ of the total carbon $(\mathrm{TC}=\mathrm{EC}+\mathrm{OC})$. In winter, however, it was the $\mathrm{BB}$ that was a major source $(40 \%)$ of OC. Technological improvements and control measures for various BB appliances, together with efficient education and training of their users, in particular on the admissible fuel types, offer an important potential for improving the air quality in Budapest, and likely in other cities as well.

Aerosol samples were also collected by a MOUDI cascade impactor in central Budapest in winter 2017, and were analysed for LVG, MAN, GAN and for K. Detailed mass size distributions were determined in an aerodynamic diameter range of 0.053-9.9 $\mu \mathrm{m}$. There were 3 modes identified in the size distributions of the monosaccharide anhydrides with typical mass median aerodynamic diameters (MMADs) and relative modal concentrations (RMCs) of $0.42 \mu \mathrm{m}$ and $90 \%, 1.62 \mu \mathrm{m}$ and up to $9 \%$, and $0.11 \mu \mathrm{m}$ and up to $9 \%$, respectively. The modes were assigned to the condensation and droplet submodes of a dominant accumulation mode and to a minor accumulation mode, respectively. The former 2 modes were generated by $\mathrm{BB}$, while the latter mode was explained by another source type with higher burning temperature than $\mathrm{BB}$, which is likely lignite combustion.

Further and more detailed results, conclusions and interpretations achieved within the framework of the BpART Laboratory can be found in our articles listed above and in dependent references therein, or on the webpage of the laboratory. 